\title{
e-Participation Experiences and Local Government in Catalonia: An Explanatory Analysis
}

\author{
Clelia Colombo \\ Researcher, Autonomous University of Barcelona, Av. Diagonal 409, \\ 08008 Barcelona, Spain \\ ccolombo@gencat.cat
}

\begin{abstract}
This research analyzes the main explanatory factors in the impulse of citizen participation experiences in public decision-making, both online and offline, looking for differences and similarities regarding Internet use for participation. It focuses the analysis in Catalonia, one of the Spanish and European Union geographical areas that have headed the impulse of participatory experiences. It focuses on the local level of government, a prolific space for these activities. Anyway, their impulse among different municipalities has been very heterogeneous and data has not been collected in a systematic way. In general terms the analyses show that political variables such as the political party of the mayor or electoral abstention rate would be explanatory for promotion of e-Participatory experiences, as well as variables relating to the participative context of the municipality or population size.
\end{abstract}

Keywords: e-Participation, citizen participation, Internet.

\section{Introduction}

The end of the 20th century and the beginning of 21 st have been marked by the revolution of information and communication technologies (from here on ICT), which burst onto the industrial era causing a change of paradigm toward the network society [10]. In this same period of time the old representative democratic system has fallen victim to a situation of democratic disaffection, meaning a lack of citizen confidence and participation in its institutions [29]. In this context, new participative practices are arising with the aim of approaching political representatives and citizens. We are talking about citizen participation understood as citizen participation experiences in public decision-making.

Incorporation of ICT in politics has introduced fundamental changes in democratic political systems [11][13][27]. Depending on the model of political management in which they are incorporated, we find models of e-Administration, e-Government or eGovernance (where e-Participation experiences are included). ICT are facilitating these practices with more extensive and direct information and greater communication between political representatives and citizens. Even so, we find important differences in the impulse and development of electronic participatory experiences (e-Participation). Thus, several questions arise: What fosters promotion of e-Participatory experiences? Which factors determine its development? 
Literature related to the study of incorporation of ICT in politics has been focused mainly on e-Government [32][35][36]. However, there are fewer studies related to ICT incorporation in democratic innovation mechanisms such as citizen participation [25][18].

Literature on citizen e-Participation has been based mainly on case studies of concrete experiences [14][3][16] and comparative empirical studies are scarce and incipient [28][24]. Moreover, existing research is mostly descriptive and evaluative, leaving out of the analysis the study of a varied set of explanatory factors of the eParticipation experiences. This paper analyzes the main explanatory factors in the generation of institutionalized citizen participation experiences that do or do not incorporate ICT in their development, focusing analysis on variables that have been little studied by e-Participation literature such as political, sociological or contextual variables.

\section{The State of the Art in ICT and Citizen Participation}

\subsection{Democratic Deficit and Citizen Participation}

The beginning of the new millennium has been marked by a political legitimacy crisis. This phenomenon -democratic disaffection [29]-, involves loss of citizens' confidence in their political representatives and the crisis of state institutions and parties.

Even so, in the same space of time, there has been a revitalization of civil society and citizens have adopted a more critical and reflective role requiring a greater degree of cooperation and interaction with the State. Thus, we find new forms of citizen participation. In this context there has been a change in the traditional conception of doing politics, introducing some transition experiences form traditional government to a new form of relational government which incorporates complexity elements, as well as all stakeholders' participation -governance-. It fosters increased citizen participation in public decision-making [9].

Citizen participation in the public sphere is diverse and includes different forms and intensity, drawing on a wide variety of situations from institutionalized participation promoted by public administrations, to participation in social movements or civic networks. This research focuses on the study of innovative citizen participation experiences promoted by local public administrations, where participatory experiences have had a better reception due to the greater proximity between citizens and representatives [5][31][19].

\subsection{Incorporation of ICT in Citizen Participation}

Incorporation of ICT in politics has introduced fundamental changes in politics and has meant new relationship possibilities between citizens and political representatives. Depending on the public management model to which they are incorporated they constitute models of e-Administration, e-Government or e-Governance, in which eParticipation experiences are encompassed [21][20][4][22].

ICT introduce strong technical improvements which can lead to the improvement of information, communication, consulting, deliberation and decision channels, 
making them more immediate, simple and effective [12]. ICT facilitate closer and more personalized communication [10] and allow taking part more directly and collectively in the political system. ICT also allow minimizing time and distance problems, reduce the costs of organization and enable communication without technological limits.

Thus, the network would make it possible to advance toward new forms of politics and citizen participation. Even so, there are some limits such as the digital divide [34][2]. Therefore, ICT have to be used as a complement of traditional analogous political practices [20].

e-Participation experiences turned up at the end of the eighties and the nineties, with the incorporation of technologies such as telephone, television or more recently Internet, into democratic innovation mechanisms. In recent years e-Participation experiences have developed immensely. Even so, there are difficulties in achieving radical changes in political systems through technological mechanisms [27][16] and we find important differences in the impulse of e-Participation experiences.

\section{The Case of Catalonia}

The study object is delimited as initiatives in the area of Catalonia where numerous participative experiences have been carried out and that is one of the leading European regions in terms of participatory experiences. Since the eighties it has enjoyed important support for participatory experiences promoted by local governments [7], heading the impulse of citizen participation in the Spanish case [15]. There are numerous participatory initiatives, cooperation and exchange networks, a common general strategy for participation defined by the Catalan Government, financial resources, consortiums and resources for Information and Communication Society development, and basic political consensus for maintaining participatory initiatives.

In the eighties, the city of Barcelona played an important international leadership role in citizen participation. Later on, the Regional Government of Barcelona gave its impulse through a specialized service working transversally in all areas of local government. A set of public and private institutions -such as universities or think tanks- have offered strong support and collaboration networks to interested city councils [19]. In 2004, Directorate General for Citizen Participation of the Catalan Government was created devoted to citizen participation promotion in Catalonia.

\section{Methodology}

\subsection{Research Question and Hypothesis}

The research aims to contribute relevant information to the following initial research questions: 'Which are the main explanatory factors in the generation of citizen participation experiences promoted by local governments in Catalonia?' and 'Are there specific explanatory factors of e-Participation experiences impulse at the local level in Catalonia?'

The existing literature on e-Government and e-Governance at the local level, has studied traditionally variables of socioeconomic and technological context and 
population size. The intention is to explore the importance that political variables may have in the generation of participatory experiences and electronic experiences. This research sets out the following hypotheses:

- The political party in charge of the city council influences participatory experiences. Thus, political parties on the left would promote more experiences [15][6][31].

- Political electoral participation influences participatory experiences. So, the higher the abstention rate, the greater the probability of finding participatory experiences [6].

- Participatory context influences in participatory experiences. Thus, the stronger the participatory context, the higher citizen participation experiences promotion [23].

- Technological context would influence the impulse of e-Participation experiences, so the more technological the municipality, the higher e-Participation experiences promotion.

- The greater the population size, the higher the citizen participation experiences promotion [30][17][6][8].

\subsection{Dependent Variable}

This research aims to explain the following dependent variables:

- Citizen participation experiences in public policy development, both online and offline, such as: participatory experiences in urban plans, municipality's budget, or other public policies.

- Participatory websites' functionalities such as: mailboxes, e-mails, complaints and suggestions mailbox, forums, blogs, surveys, consultations or documents.

Citizen participation refers to any voluntary action by citizens more or less directly aimed at influencing the management of collective affairs and public decision-making [33]. Following the Arnstein ladder of participation [1], we consider as participatory initiatives those that include a level of interaction and influence in the decisionmaking process -from elemental to more in-depth participation levels: information, communication, consultation, deliberation and decision-making-. These experiences can be continuous or limited in time, so we can have punctual experiences, processes and permanent experiences.

\subsection{Explanatory Variables}

This paper aims to analyze the explanatory variables of citizen participation experiences and channels at the local level with the aim of contrasting and further analyzing previous research and literature [15][30][17][6][8][31]. It studies political, sociological, economic and technological explanatory variables, which have been grouped into different analytical categories:

- Political context: local government's political color, electoral abstention rate.

- Participatory context: e-Participation platforms, legal regulation of citizen participation, citizen participation department and number of consultative boards. 
- Socioeconomic context: Gross Domestic Product per inhabitant, average age of the population and population with Spanish nationality.

- Technological context: through the proxy of Internet bandwidth percentage of the municipality's population ${ }^{\mathrm{i}}$.

- Municipality size: number of inhabitants in the municipality.

\subsection{Study Object and Sample}

We analyze citizen participatory experiences promoted by Catalan local governments between January 2007 and June 2009. Catalonia has 946 municipalities distributed as shown by table 1 . Even though more than $50 \%$ of municipalities have less than 1000 inhabitants, $89.27 \%$ of the population is concentrated in municipalities with more than 5000 inhabitants and $54.52 \%$ in municipalities of more than 50000. Previous studies [30][17][8], show that population size is a determining factor for the development of web sites, online services and channels of interaction. Other studies show that in Catalonia medium-size and large municipalities have led development of citizen participatory experiences [23][7]. Taking all this into consideration, the paper analyzes a sample of 199 Catalan municipalities: all Catalan municipalities with more than 5000 inhabitants ${ }^{\mathrm{ii}}$.

Table 1. Distribution of Catalan municipalities by population

\begin{tabular}{|l|c|c|c|}
\hline Population sections & $\begin{array}{c}\text { Number of } \\
\text { municipalities }\end{array}$ & \% Population & $\begin{array}{c}\% \\
\text { Municipalities }\end{array}$ \\
\hline Less than 1000 & 490 & 2.61 & 51.8 \\
\hline 1000 to 5000 & 256 & 8.12 & 27.1 \\
\hline 5001 to 20000 & 139 & 18.45 & 14.7 \\
\hline 20001 to 50000 & 38 & 16.30 & 4.0 \\
\hline More than 50000 & 23 & 54.52 & 2.4 \\
\hline Total & 946 & 100 & 100 \\
\hline
\end{tabular}

\subsection{Research Methods}

A quantitative approach was adopted. In the moment of elaborating this research any public administration, private company or university has carried out an exhaustive collection of e-Participation experiences in the Catalan area. Therefore, a database was set up by the author that collected the distribution of the dependent variable and the explanatory variables in each municipality of the sample. It was constructed between June and October 2009, gathering data from different sources: the analysis of several existing non-exhaustive databases on participatory experiences ${ }^{\text {iii }}$, the observation of eParticipation experiences web sites, the study of municipalities' web sites, the use of aggregated databases on economic, socio-demographic and technological characteristics of municipalities, or public information on municipality's resources and its legal and political framework. The information was completed through direct contact with city councils, when necessary. The construction of this database allows bringing up a quantitative analysis of the main explanatory factors of the generation of these experiences. With this objective, multivariate explanatory statistical analyses are carried out, relating the dependent variable with the different proposed explanatory ones. 


\section{Analysis and Findings}

The study object is structured in different ways regarding Internet use, time sustainability and the participatory level achieved. Thus, we have the following dependent variables: online and offline participatory experiences, e-Participation experiences, offline participation experiences, total of e-Participation, total of participation, e-Participation index and participation index. Table 2 presents the main statistical sample measures for each one of the analysis' variables.

Table 2. Sample values of variables analysis

\begin{tabular}{|c|c|c|c|c|c|c|}
\hline & Variables & $\mathrm{N}$ & Min. & Max. & Mean & Std. Dev. \\
\hline \multirow{7}{*}{ 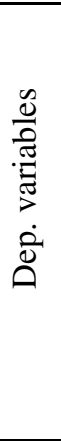 } & $\begin{array}{l}\text { Online \& offline } \\
\text { participatory } \\
\text { experiences }\end{array}$ & 199 & 0 & 6 & 1.29 & 1.54 \\
\hline & \begin{tabular}{|l|} 
e-Participation \\
experiences
\end{tabular} & 199 & 0 & 6 & 0.77 & 1.21 \\
\hline & $\begin{array}{l}\text { Offline participation } \\
\text { experiences }\end{array}$ & 199 & 0 & 5 & 0.52 & 0.92 \\
\hline & \begin{tabular}{|l|} 
Total of e- \\
Participation $^{\text {iv }}$ \\
\end{tabular} & 199 & 0 & 15 & 5.65 & 2.67 \\
\hline & Total of participation $^{v}$ & 199 & 0 & 15 & 6.18 & 2.95 \\
\hline & e-Participation index ${ }^{\mathrm{vi}}$ & 197 & 1 & 7 & 2.81 & 1.66 \\
\hline & \begin{tabular}{|l|} 
Participation index \\
vii \\
\end{tabular} & 197 & 1 & 3 & 1.75 & 0.75 \\
\hline \multirow{16}{*}{ 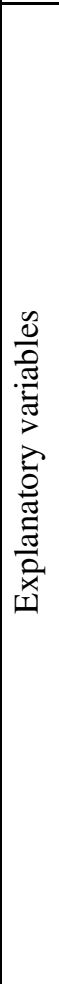 } & $\begin{array}{l}\text { Ln_population07thousa } \\
\text { nds }\end{array}$ & 199 & 1.62 & 5.53 & 2.67 & 0.89 \\
\hline & \begin{tabular}{|l|} 
Population07thousands \\
\end{tabular} & 199 & 5.06 & 251.85 & 24.29 & 36.28 \\
\hline & \begin{tabular}{|l|}
$\%$ Electoral \\
abstention $^{\text {viii }}$ \\
\end{tabular} & 199 & 29.44 & 50.47 & 38.66 & 4.32 \\
\hline & $\begin{array}{l}\% \text { Bandwidth } \\
\text { connection }\end{array}$ & 199 & 8.4 & 29.4 & 17.88 & 3.50 \\
\hline & GDP per inhabitant & 169 & 4.10 & 81.10 & 20.48 & 10.83 \\
\hline & Average age & 199 & 33.54 & 45.26 & 38.83 & 1.87 \\
\hline & $\%$ Spanish nationality & 199 & 53.15 & 97.92 & 87.63 & 7.50 \\
\hline & $\begin{array}{l}\text { Mayor of PSC }{ }^{\mathrm{ix}} \& \\
\text { locals }\end{array}$ & 199 & 0.00 & 1.00 & 0.50 & 0.50 \\
\hline & $\begin{array}{l}\text { Mayor of ERC } \text { ER }^{x} \\
\text { Locals }\end{array}$ & 199 & 0.00 & 1.00 & 0.10 & 0.31 \\
\hline & $\begin{array}{l}\text { Mayor of ICV }{ }^{\mathrm{xi}} \& \\
\text { locals }\end{array}$ & 199 & 0.00 & 1.00 & 0.01 & 0.12 \\
\hline & \begin{tabular}{|l|} 
Mayor of $\mathrm{PP}^{\mathrm{xii}}$ \\
\end{tabular} & 199 & 0.00 & 1.00 & 0.005 & 0.07 \\
\hline & \begin{tabular}{|l|} 
Mayor of local \& \\
indep. lists
\end{tabular} & 199 & 0.00 & 1.00 & 0.07 & 0.26 \\
\hline & \begin{tabular}{|l|} 
Participation \\
formalization factor
\end{tabular} & 190 & -0.99 & 3.35 & 0.00 & 1.00 \\
\hline & \begin{tabular}{|l|} 
e-Participation \\
Platform \\
\end{tabular} & 199 & 0 & 1 & 0.22 & 0.42 \\
\hline & $\begin{array}{l}\% \text { Post-compulsory } \\
\text { education }\end{array}$ & 199 & 16.13 & 60.71 & 31.63 & 7.90 \\
\hline & $\begin{array}{l}\text { Participatory web } \\
\text { functionalities }\end{array}$ & 199 & 0 & 10 & 4.87 & 1.92 \\
\hline
\end{tabular}


Table 3. Regression analysis coefficients

\begin{tabular}{|c|c|c|c|c|c|c|c|c|c|c|c|c|c|c|}
\hline \multirow{3}{*}{ Model } & \multicolumn{6}{|c|}{ Number of experiences } & \multicolumn{4}{|c|}{ Total of e-Participation } & \multicolumn{4}{|c|}{ e-Participation index } \\
\hline & \multicolumn{2}{|c|}{$\begin{array}{c}\begin{array}{c}\text { Online \& } \\
\text { offline } \\
\text { experiences }\end{array} \\
\end{array}$} & \multicolumn{2}{|c|}{$\begin{array}{c}\text { Online } \\
\text { experiences }\end{array}$} & \multicolumn{2}{|c|}{$\begin{array}{c}\text { Offline } \\
\text { experiences }\end{array}$} & \multicolumn{2}{|c|}{$\begin{array}{c}\text { Total e- } \\
\text { Participation }\end{array}$} & \multicolumn{2}{|c|}{$\begin{array}{c}\text { Total } \\
\text { Participation }\end{array}$} & \multicolumn{2}{|c|}{$\begin{array}{c}\text { e-Participation } \\
\text { index }\end{array}$} & \multicolumn{2}{|c|}{$\begin{array}{c}\text { Participation } \\
\text { index }\end{array}$} \\
\hline & Coeff. & $\begin{array}{l}\text { Std. } \\
\text { error }\end{array}$ & Coeff. & $\begin{array}{l}\text { Std. } \\
\text { error }\end{array}$ & Coeff. & $\begin{array}{l}\text { Std. } \\
\text { error }\end{array}$ & Coeff. & $\begin{array}{l}\text { Std. } \\
\text { error }\end{array}$ & Coeff. & $\begin{array}{l}\text { Std. } \\
\text { error }\end{array}$ & Coeff. & $\begin{array}{l}\text { Std. } \\
\text { error }\end{array}$ & Coeff. & $\begin{array}{l}\text { Std. } \\
\text { error }\end{array}$ \\
\hline $\begin{array}{l}\text { Ln } \\
\text { Population }\end{array}$ & $0.433 * *$ & 0.179 & $0.288 * *$ & 0.143 & 0.143 & 0.130 & $0.627 * *$ & 0.288 & $0.785 * *$ & 0.314 & $0.309^{*}$ & 0.181 & $0.208 * *$ & 0.094 \\
\hline $\mid \begin{array}{ll}\text { Mayor } & \text { of } \\
\text { ICV \& loc }\end{array}$ & 1.394 & 0.933 & $1.878 * *$ & 0.748 & 0.032 & 0.677 & 1.723 & 1.512 & 1.734 & 1.647 & 0.770 & 0.948 & -0.469 & 0.495 \\
\hline $\begin{array}{l}\text { Mayor of } \\
\text { PSC \& loc }\end{array}$ & -0.193 & 0.237 & 0.007 & 0.190 & -0.199 & 0.172 & 0.139 & 0.385 & -0.053 & 0.419 & 0.059 & 0.241 & -0.100 & 0.126 \\
\hline $\begin{array}{l}\text { Mayor of } \\
\text { ERC \& } \\
\text { locals }\end{array}$ & -0.118 & 0.345 & 0.005 & 0.277 & -0.138 & 0.250 & -0.365 & 0.559 & -0.502 & 0.609 & 0.120 & 0.351 & 0.001 & 0.183 \\
\hline $\begin{array}{l}\text { Mayor of } \\
\mathrm{PP}\end{array}$ & 0.791 & 1.263 & -0.283 & 1.013 & 1.041 & 0.916 & -0.509 & 2.049 & 0.550 & 2.232 & 0.980 & 1.285 & 0.688 & 0.671 \\
\hline $\begin{array}{l}\text { Mayor of } \\
\text { local \& } \\
\text { ind. lists }\end{array}$ & 0.226 & 0.402 & 0.084 & 0.322 & 0.141 & 0.291 & 0.651 & 0.649 & 0.806 & 0.707 & 0.634 & 0.407 & 0.182 & 0.213 \\
\hline $\begin{array}{l}\text { Part. } \\
\text { Formaliza } \\
\text { tion } \\
\text { factor }\end{array}$ & $0.396 * *$ & 0.123 & 0.112 & 0.099 & $0.273 * *$ & 0.089 & $0.411 * *$ & 0.198 & $0.705 * * *$ & 0.216 & $0.299 * *$ & 0.124 & $0.220 * * *$ & 0.065 \\
\hline $\begin{array}{l}\text { e- } \\
\text { Participati } \\
\text { on } \\
\text { platform }\end{array}$ & $1.335^{* * *}$ & 0.268 & $1.404 * * *$ & 0.214 & -0.044 & 0.194 & $3.183 * * *$ & 0.401 & $3.168 * * *$ & 0.437 & $2.063 * * *$ & 0.252 & $0.457 * * *$ & 0.131 \\
\hline $\begin{array}{l}\% \\
\text { Electoral } \\
\text { abstention }\end{array}$ & -0.021 & 0.032 & $-0.049 *$ & 0.026 & 0.025 & 0.023 & $-0.088^{*}$ & 0.052 & -0.063 & 0.057 & $-0.035 *$ & 0.033 & -0.003 & 0.017 \\
\hline $\begin{array}{ll}\text { GDP } & \text { per } \\
\text { inhabitant }\end{array}$ & -0.005 & 0.010 & -0.004 & 0.008 & -0.002 & 0.007 & 0.006 & 0.017 & 0.005 & 0.018 & 0.007 & 0.010 & 0.002 & 0.005 \\
\hline $\begin{array}{l}\% \\
\text { Bandwidth } \\
\text { connection }\end{array}$ & 0.045 & 0.038 & 0.024 & 0.030 & 0.022 & 0.027 & 0.042 & 0.061 & 0.065 & 0.067 & 0.038 & 0.039 & 0.022 & 0.020 \\
\hline $\begin{array}{l}\text { Average } \\
\text { age }\end{array}$ & 0.003 & 0.063 & $-0.087 *$ & 0.050 & $0.085^{*}$ & 0.045 & -0.074 & 0.102 & 0.013 & 0.111 & -0.040 & 0.064 & 0.020 & 0.033 \\
\hline $\begin{array}{cr}\% & \text { Spanish } \\
\text { nationality }\end{array}$ & 0.012 & 0.014 & 0.004 & 0.011 & 0.008 & 0.010 & -0.011 & 0.023 & -0.003 & 0.025 & 0.000 & 0.014 & 0.000 & 0.007 \\
\hline $\begin{array}{l}\% \quad \text { Post- } \\
\text { compulso } \\
\text { ry educ. }\end{array}$ & -0.009 & 0.017 & -0.002 & 0.013 & -0.007 & 0.012 & 0.009 & 0.027 & 0.002 & 0.029 & 0.007 & 0.017 & -0.003 & 0.009 \\
\hline $\begin{array}{l}\text { Part. web } \\
\text { functional } \\
\text { ities }\end{array}$ & 0.081 & 0.060 & 0.049 & 0.048 & 0.028 & 0.044 & & - & & - & & - & - & - \\
\hline Constant & -1.268 & 3.759 & 4.110 & 3.014 & $-4.948 *$ & 2.726 & 9.309 & 6.078 & 4.294 & 6.622 & 3.251 & 3.812 & 0.204 & 1.990 \\
\hline $\begin{array}{l}\text { NAdjuste } \\
\mathrm{d} \mathrm{R}^{2}\end{array}$ & $\begin{array}{l}169^{\text {xiv }} \\
0.426\end{array}$ & & $\begin{array}{l}169 \\
0.419\end{array}$ & & $\begin{array}{l}169 \\
0.124\end{array}$ & & $\begin{array}{l}169 \\
0.460\end{array}$ & & $\begin{array}{l}169 \\
0.479\end{array}$ & & $\mid \begin{array}{l}169 \\
0.461\end{array}$ & & $\begin{array}{l}169 \\
0.279\end{array}$ & \\
\hline
\end{tabular}

$* \mathrm{p}<0.1 * * \mathrm{p}<0.05 * * * \mathrm{p}<0.001$ Source: own elaboration 
In order to analyze the association between citizen participation experiences and the explanatory variables, controlling by the factors that might affect them, we performed seven multiple linear regression analyses. As can be observed in table 3, there are some differences and similarities in the multiple linear regression analyses that were carried out.

\section{1 e-Participation Experiences}

To study the explanation of Internet incorporation in citizen participation experiences, we compared multiple regression models for online experiences, total of eParticipation and e-Participation index. The first variable measures the number of eParticipation experiences promoted; the second measures all electronic experiences, adding to the previous ones the participatory website functionalities; lastly, eParticipation index measures the experiences' degree, considering together their number, participation level and time sustainability.

The analyses show that explanatory variables are very similar in the three cases, even though we observe differences in some variables. As table 3 shows, Internet use for citizen participation would be explained in the three models by the population size, the existence of an e-Participation platform and the electoral abstention rate. Thus, there would be a greater electronic participation in larger municipalities, with an e-Participation platform and with lower electoral abstention.

On the other hand, we find some differences, worth pointing out. The variable of participation formalization factor is not significant in the explanation of the online experiences' number, while it is explanatory for the total of e-Participation and for the e-Participation index. We also find differences in the model of the number of eParticipation experiences promotion, where having a mayor from ICV (a party on the left) and a low average population age would be explanatory, while they would not in the other two models.So, we could think that when we deal with more stable eParticipation structures -as in the cases of e-Participation index or the total of eParticipation- having a strong participation formalization would be a key factor in the use of Internet for citizen participation. Instead, when we only study the number of experiences, having a mayor from ICV or a young population, would be explanatory of their impulse. This could be showing that Internet incorporation in participatory experiences would be more favorable in municipalities with these characteristics, even though these characteristics would not be explanatory of the level or sustainability of these experiences.

\subsection{Offline Participatory Experiences}

Secondly, we dealt with the explanatory factors of offline participation, analyzing the variables offline experiences and participation index. The analyses show that there is only one common variable explanatory for both offline models: the participation formalization factor, which would explain the number of experiences promoted, their participative level and their time sustainability. On the other hand, we find differences in the significance of other variables such as 'average population age', which would explain the number of experiences promoted while not explaining their degree in terms of level and sustainability. It is worth mentioning that although in the 
explanation of the number of e-Participation experiences age had a negative coefficient, in this case its coefficient is positive. Finally, the variables of population size and electronic platform for citizen participation are explanatory for the degree of offline experiences, while they are not for the number of experiences promoted by municipalities.

\subsection{Online and Offline Citizen Participation}

Finally, this section studies jointly citizen participation experiences carried out offline and using the Internet. Thus, we analyze variables of offline and online experiences, and total of participation.

The developed analyses show that for both models, variables of population size, electronic platform for citizen participation and the participation formalization factor are explanatory. Even though the values of the coefficients are quite different, it is worth pointing out that their signs are equal, being all positive.

Thus, it could be stated that even in the explanation of the number of participatory experiences (online and offline) and in the explanation of these experiences, taking also into account the web site participatory functionalities, the population size would be explanatory. So, the greater the number of inhabitants, the higher the number of experiences promoted, even though its effect would be greater in the case of 'total of participation'. Likewise, municipalities with electronic citizen participation platforms would promote more experiences than municipalities without such a platform. Thus, it could be stated that this variable -although having a positive effect in both dependent variables- would have a stronger effect when it comes to explaining experiences and web site functionalities, than if only experiences are explained. This could mean that the use of e-Participation platforms could be related to the opening of participatory functionalities in municipal web sites and could be indicative of a stronger participatory culture in the municipality, which would also have effects on the offline participatory experiences. Finally, municipalities with a higher participation formalization factor would promote more participatory experiences. Again, the coefficient of the variable is higher in the case of the explanation of the experiences plus web site functionalities than in the case of the explanation of the experiences.

\section{Conclusions and Discussion}

This paper has analyzed the possible explanatory factors of citizen participatory experiences promoted at the local level in Catalonia, both online and offline. It has analyzed the most relevant variables considered by the literature: political, technological and socioeconomic variables, and the size of the municipality. We have studied their influence in the number of experiences promoted and in their degree of participatory level and time sustainability reached. We also conducted analyses in order to evaluate whether the explanatory factors for offline participation can also be explanatory for e-Participation experiences.

Regarding the hypotheses, the analyses show that political variables would be explanatory for e-Participation experiences in Catalonia, as suspected, but they won't be for the offline ones. This may indicate a greater generalization of offline 
experiences, so their development would not be any longer explained by a left political color, as previous research indicated [15][6][31] or by the electoral abstention rate [6][7].

Electoral abstention rate would be explanatory for e-Participation in the sense that the lower the abstention rate, the higher the e-Participation. This would be contrary to previous research [6], even though previous research analyzed offline experiences. This may indicate that e-Participation experiences would still be pioneer and innovative, and would need a more participatory environment to be promoted. So, political variables would be explanatory for them, but not for offline experiences, which would be currently more widespread than in previous years.

On the participatory context, in general terms we found empirical evidence in all the models but the online experiences, that the higher the formalization of citizen participation in the municipality, the greater the citizen participatory experiences. So, there would be a positive relation between promoting participatory experiences and having formal participation councils, legal regulation and a special department in the city council. This would be in line with our hypothesis and with previous research [23].

Unfortunately the data used does not allow us to find significance in the technological variables collected. Nonetheless, it worth mentioning that having an eParticipation platform is significant in all the models but the offline experiences one. This could be due to a possible relation between having an e-Participation platform and being a more participatory oriented municipality.

Regarding population size, it could be said that the greater the population size, the greater the citizen participation, both online and offline, as we had expected and in line with previous research [30][17][6][8]. Even though, in the case of offline experiences, the non-significance of this coefficient may be showing a generalization of those experiences in all the municipalities.

Finally, with the exception of the age, none of the socioeconomic variables explains online or offline participation. So, we could conclude that promotion of participatory experiences would be tied to political context and participatory will variables, not to differential population characteristics of the municipality. This would be derived from the non-significance of the analyzed socioeconomic variables, as well as from the significance of the age variable in the number of experiences explanation, which would favor e-Participation in young populations and offline participation in older ones. Thus, participatory experiences would be related to the political context of the municipality and strategies and tools that reflect the interest in developing them. So, we could conclude that in this moment, e-Participation would not be yet a generalized tool, but it would already represents the democratic innovation arrow.

\section{References}

1. Arnstein, S.R.: A ladder of citizen participation. Journal of the American Institute of Planners 35(4), 216-224 (1969)

2. Barber, B.: To what extent are new telecommunication technologies democratic? IDP. Internet, Derecho y Política, 3 (2006), http: / / www . uoc . edu / idp 
3. Barrat, J., Reniu, J.M.: Democracia electrónica y participación ciudadana. Informe sociológico y jurídico de la consulta ciudadana Madrid Participa. Ayuntamiento de Madrid / Scytl / Accenture, Madrid (2004)

4. Bellamy, C.: Modelling electronic democracy: towards democratic discourses for an information age. In: Hoff, J., Horrocks, I., Tops, P. (eds.) Democratic Governance and New Technology. Routledge, London (2000)

5. Blanco, I., Gomà, R.: Gobiernos locales y redes participativas. Ariel, Barcelona (2002)

6. Blanco, I., Font, J.: La participación local: factores estructurales, ideológicos e instrumentales. In: Working Papers Online Series, Universidad Autónoma de Madrid (2005), http: / / www . uam. es / centros / derecho/cpoliticapapers.htm

7. Borge, R., Colombo, C., Welp, Y.: Online and offline participation at the local level. Information, Communication \& Society 12(6), 899-928 (2009)

8. Brown, M., Schelin, S.: American Local Governments: Confronting the E-government Challenge. In: Drüke, H. (ed.) Local Electronic Government: A Comparative Study. Routledge, New York (2005)

9. Brugué, Q., Gomà, R.: Gobierno local y políticas públicas. Ariel, Barcelona (1998)

10. Castells, M.: La era de la Información, La sociedad red, vol. I. Alianza, Madrid (2000)

11. Ciulla, E., Nye, J.S. (eds.): Governance.com: Democracy in the Information Age. Brookings Institution Press, Washington (2002)

12. Clift, S.: The E-democracy E-book, Publicus.net (2000), http: / / www . publicus.net

13. Clift, S.: E-Democracy, E-governance and Public Net-Work, Publicus.net (2003), http: / /www.publicus. net

14. Coleman, S., Gøtze, J.: Bowling Together: Online Public Engagement in Policy Deliberation. BT \& Hansard Society, London (2001)

15. Colino, C., Del Pino, E.: Un fantasma recorre Europa: Renovación democrática mediante iniciativas de promoción participativa en los gobiernos locales. II Jornadas de Sociología Política, UNED, Madrid (September 11-12, 2003)

16. Colombo, C.: e-Participació: la incorporació d'Internet en la presa de decisions públiques. El cas de Consensus, ciutadans en xarxa' in Revista Catalana de Sociología (2007)

17. Criado, J.I.: Construyendo la e-Administración Local. EuroGestión Pública, Madrid (2004)

18. Finquelievich, S., Baumann, P., Jara, A.: Nuevos paradigmas de participación ciudadana a través de las tecnologías de la información y la comunicación (2001),

http: / / www. links.org.ar

19. Font, J., Galais, C.: Experiències de democràcia participativa a Catalunya: un mapa analític, Generalitat de Catalunya. Direcció General de Participació Ciutadana, Barcelona (2009)

20. Hacker, K., Van Dijk, J.: Digital Democracy. Issues of Theory \& Practice. Sage Publications, London (2000)

21. Hagen, M.: A Typology of Electronic Democracy (1997), http://www.uni-giessen.de/fb03/vinci/labore/netz/hag_en.htm

22. Hoff, J., Horrocks, I., Tops, P. (eds.): Democratic Governance and New Technology. Routledge, Londres (2000)

23. IGOP: La participació ciutadana als petits municipis (2005), http: / /www10.gencat. cat/drep

24. Jensen, M., Danzinger, J., Venkatesh, A.: Civil Society and Cyber Society: The Role of the Internet in Community Associations and Democratic Politics. The Information Society 23, 39-50 (2007) 
25. Macintosh, A., Whyte, A.: Evaluating how e-Participation changes local democracy. In: Irani, Z., Ghoneim, A. (eds.) Proceedings of the e-Government Workshop, eGov'06. Brunel University, London (2006)

26. Norris, P. (ed.): Critical citizens. Oxford University Press, Oxford (1999)

27. Norris, P.: Building knowledge societies: the renewal of democratic practices in knowledge societies. UNESCO World Report (2004), http: / /www.pippanorris.com

28. Pratchett, L.: Making local e-democracy work? In: Virapatirin, M., Peixoto, T. (eds.) eAGORA, Le Livre Blanc de la e-démocratie locale: Réflexions et Perspectives. Ville d'Issy-les-Moulineaux, Paris (2006)

29. Putnam, R., Goss, K.: El declive del capital social. Un estudio internacional sobre las sociedades y el sentido comunitario. Circulo de lectores. Galaxia Gutenberg, Barcelona (2003)

30. Salvador, M., CortéS, R., Sánchez, R., Ferrer, L.L.: Els ajuntaments de Catalunya a Internet. Estudis de Ciències Polítiques i Gestió Pública. UPF, Barcelona (2004),

http: / / www . upf . edu / cpgp/

31. Schneider, C.: La participación ciudadana en el gobierno de Buenos Aires (1996-2004): El contexto político como explicación. In: CIDOB Working papers, CIDOB (2007)

32. United Nations, UN Global e-Government Survey. United Nations online Network in Public Administration and Finance, UNPAN, New York (2004)

33. Verba, S., Schlozman, K.L., Bredy, H.E.: Voice and Equality. Civic Voluntarism in American Politics. Harvard University Press, Cambridge (1995)

34. Warshauer, M.: Technology and social inclusion: Rethinking digital divide. Massachusetts Institute of Technology, Massachusetts (2003)

35. West, D.: E-Government and the transformation of service delivery and citizen attitudes. Public Administration Review 64 (2004)

36. Wong, W., Welch: Does e-government promote accountability? A comparative analysis of website openness and government accountability. Governance 17 (2004)

Notes:

i Internet bandwidth percentage of the municipality's population is the only ICT variable disintegrated and representative at the municipal level in Catalonia.

ii The city of Barcelona is not included in the sample due to several reasons. Its complex administrative structure, the city council's high participatory activity and the lack of systematization and information centralization of the participatory experiences promoted entail a lack of exhaustive and systematic information on all the experiences promoted. Moreover, Barcelona city council tried to gather all this information through several research projects, which were rejected due to the great amount of resources required.

iii Databases used to collect data are: Democratic Innovation program and Local Government of Catalonia; the Catalonia's Public Administration School Database; the Participatory Democracy Local Observatory; the Participatory Democracy International Observatory; the Pi Sunyer Foundation good practices bank; database of the Directorate General for Citizen Participation; as well as information coming from other municipal studies or web sites.

${ }^{\text {iv }}$ The total of e-Participation is the sum of the number of e-Participation experiences and the participatory website functionalities.

$v$ The total of participation is an addition of eParticipation experiences, plus offline participation experiences, plus participatory website functionalities. 
${ }^{\text {vi }}$ Measures eParticipaiton taking into account the number of eParticipatory experiences, its participatory level (information, communication, consultation, deliberation, decision) and its temporal sustainability (process, punctual or permanent). It also measures participatory website functionalities and their participatory level. This index is constructed through a weight average of these variables, weighting last two variables 0'5 (participatory website functionalities are important for eParticipation but do not consitute complete eParticipation expericences themselves). High values make reference to municipalities with high eParticipation (big number, of high participatory level and time lasting experiences).

${ }^{\text {vii }}$ Measures citizen participation taking into account the number of offline participatory experiences, its participatory level and its temporal sustainability. The same weight is assigned to each one of those variables.

viii This variable measures the average electoral abstention rate in each municipalitiy taking into account the last electoral participation rates (general elections 2008, regional elections 2006 and local elections 2007).

${ }^{\text {ix }}$ Partit dels Socialistes de Catalunya (PSC) is a centre-left party that has led Catalan government since 2003.

${ }^{x}$ Esquerra Republicana de Catalunya (ERC) is a left-leaning party that strives for independence of Catalonia. It is the 4th or 3rd political force, depending on the elections.

${ }^{\mathrm{xi}}$ Iniciativa per Catalunya- Els Verds (ICV) is a small left-leaning party, concentrated in larger cities, which strongly defends the carrying out of participatory initiatives.

${ }_{\text {xii }}$ Partit Popular (PP) is a right-Spanish party, which has little presence throughout Catalonia.

xiii This factor arose from a factorial analysis of the following variables: citizen participation legal regulation in the municipality, citizen participation consultative boards, citizen participation department in the city council.

xiv The difference between $\mathrm{N}=199$ as basis for the analysis and $\mathrm{N}=169$ in Table 2 is due to missing values in 30 municipalities for GDP per inhabitant variable. 